Journal of Agricultural Sciences
(Tarim Bilimleri Dergisi)

\title{
Possibilities of Use Fertilizer Industry Waste Gypsum Material of Improve Sodic and Boron Soils
}

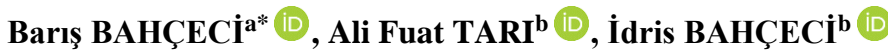

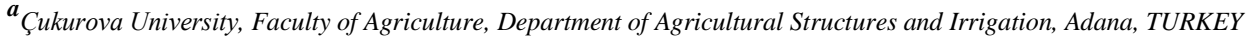

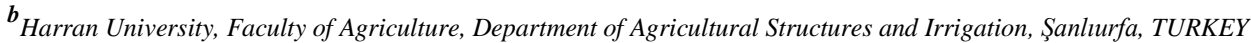 \\ ${ }^{b}$ Harran University, Faculty of Agriculture, Department of Agricultural Structures and Irrigation (Retired), Şanlurfa, TURKEY
}

ARTICLE INFO

Research Article

Corresponding Author: Barış BAHÇECİ, E-mail: baris_bahceci@hotmail.com

Received: 16 February 2020 / Revised: 08 August 2021 / Accepted: 11 August 2021 / Online: 01 September 2022

Cite this article

BAHÇECI B, TARI F A, BAHÇECI i (2022). Possibilities of Use Fertilizer Industry Waste Gypsum Material of Improve Sodic and Boron Soils. Journal of Agricultural Sciences (Tarim Bilimleri Dergisi), 28(3):449-456. DOI: 10.15832/ankutbd. 856762

\section{ABSTRACT}

The effect of the Fertilizer Industry Waste Gypsum Material (FIWGM) on the rehabilitation of barren soils has been investigated with this research. The soil improvement tests were carried out in randomized blocks with three replications and 0, 20, 40 and 60 tons ha ${ }^{-1}$ of FIWGM have been applied. By the intermittent ponding method, a total of $360 \mathrm{~cm}$ of water has been given, including $30 \mathrm{~cm}$ at each time. At the end of the trial, the application of FIWGM has showed positive effect on the physical and chemical properties of the soil. As the dose of FIWGM increased, soil infiltration rates increased, and soil sodium and boron concentrations decreased significantly. $360 \mathrm{~cm}$ of leaching water provided the removal of exchangeable sodium equivalent to 33.7 and 42.9 tons of gypsum for $100 \mathrm{~cm}$ of soil depth, with 20 and 40 tons per hectare of FWIGM applied to the test plots. The statistically significant correlation coefficient $\left(\mathrm{R}^{2}=0.921^{* *}\right)$ has been determined between the leaching water depth (Dlw)/soil depth (Ds) and the boron/initial boron remaining $(\mathrm{B} / \mathrm{Bo})$ in the soil $(\mathrm{B} / \mathrm{Bo}=0.622-0.168 \mathrm{Ln} \mathrm{Dlw} / \mathrm{Ds})$.

Keywords: Sodic soils, Industrial gypsum, Waste material, Leaching water, Boron leaching, FIWGM

\section{Introduction}

Salt-affected soils are considered to be one of the main problems affecting agriculture, as well as a global environmental problem (Martinez-Beltran \& Manzur 2005). According to the FAO/UNESCO soil map (1970-1980), the global total area of saline soils was 397 million hectares, while the total area of sodic soils 434 million hectares (FAO 2019).

A number of studies have been conducted for a long time on the use of different industrial wastes containing gypsum in the improvement and use of sodic soils (Hussain et al. 2001). For example, the addition of organic bio-ameliorants into sodic-soils has significantly increased root growth and yield of wheat (Gill et al. 2009). The application of gypsum, as well as organic fertilizer which reduces the sodicity of the soil, improves physicochemical properties by reducing pH, exchangeable sodium percentage (ESP) and bulk density and, as a result, improves the availability of nutrients in the soil (Singh et al. 2013). Matured municipal solid waste compost effectively recovered degraded soils with high soluble salt content and exchangeable sodium content (Hanay et al. 2013). In recent years, researchers have used different substances to properly treat barren lands. It was quite effective; mixtures of fly ash and sewage sludge were applied to saline-sodic soils for the purpose of soil recovery and environmentally friendly waste recycling (Örs et al. 2014). Recycled sewage sludge and fly ash allowed for cheap saline-sodic soil reclamation. The use of gypsum with biological modifications provided is more beneficial for the recovery of sodic and saline-sodic soils than for gypsum alone (Sisoday \&Vaghani 2016), the combination of farmyard manure (FYM) and gypsum has increased physiological growth (Haque et al. 2015). Gypsum and calcium chloride provided direct source of $\mathrm{Ca}^{2+}$ to replace $\mathrm{Na}^{+}$, while sulphuric acid increases the calcite dissolution (Gupta \& Abrol 1990; Mace et al. 1999; Qadir et al. 2001). Gharaibeh et al. (2010) have demonstrated that phosphoric acid can be used to reclaim saline-sodic soils, and the use of organic modification by Diacono \& Montemurro (2015) must be considered an effective measure to restore soil quality in salt-affected soils. On the other hand, with the application of domestic solid waste and farm waste, soil $\mathrm{pH}$ was lowered and the bulk density and seepage properties of the soil (Singh et al. 2017).

Global studies have demonstrated that the most reliable method to determine the reclamation criteria for saline-sodic soils with high boron content improvement is to carry out experimental trials in the problematic areas. Therefore, this study presents a paper on soil and land reclamation in the Ereğli Plain, which is located in the Center Anatolia in Turkey. The objective of the 
study was to determine reclamation criteria like required Fertilizer Industry Waste Gypsum Material (FIWGM), amount of leaching water, reclamation time, and the effect of the difference FIWGM dosages on the exchangeable sodium removal and infiltration rate of the soil for the sodic and boron soils in the area.

\section{Material and Methods}

\subsection{Trial site}

The test area is located in the Ereğli Plain, $1044 \mathrm{~m}$ above sea level, and it is a closed basin, with no outlet to discharge its waters into the sea, therefore its water is discharged to Lake Akgöl. The plain, which is the research area, has an agricultural land area of approximately 95000 ha (Figure 1).

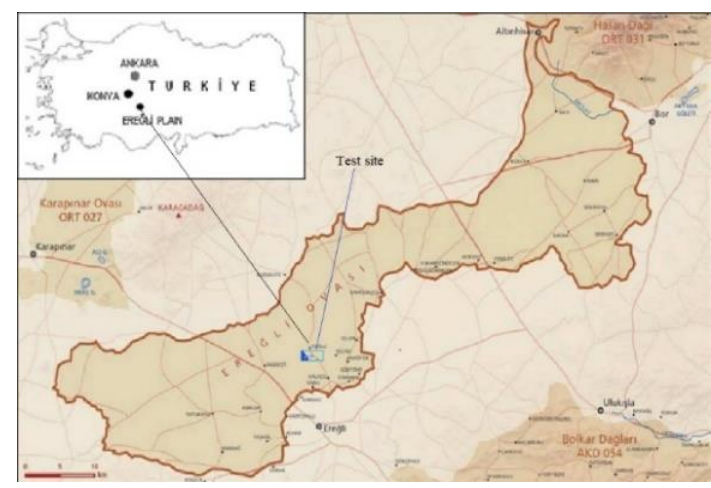

Figure 1- Geographic location of the trial

\subsection{Climate characteristics}

The region wherein the research is conducted has a semi-arid, continental climate conditions. The average annual precipitation is $320 \mathrm{~mm}, 10 \%$ of which falls in the summer, while the rest falls approximately equally in the other season. Summer is hot and dry, and it is cold in winter.

\subsection{Soil characteristics}

Research site soils have clay textures and a high amount of lime content (30-40\%) and cation exchange capacity (CEC) is low, sodium exchangeable and soil salinity is high and the dominant salt type is sulphate, while soil pH varies from 8.0 to 8.4 (Table 1).

Table 1- Soil chemical and physical properties of experimental plots before treatment

\begin{tabular}{cccccccccc}
\hline $\begin{array}{c}\text { Depth } \\
\mathrm{cm}\end{array}$ & $\mathrm{pH}$ & $\begin{array}{c}\text { Saturation } \\
\%\end{array}$ & $\begin{array}{c}E C_{e} \\
\mathrm{~S} \mathrm{~m}^{-1}\end{array}$ & $\begin{array}{c}\mathrm{CEC} \\
\mathrm{cmol}^{+} \mathrm{kg}^{-1}\end{array}$ & $\begin{array}{c}\text { Exc. Na } \\
\mathrm{cmol}^{+} \mathrm{kg}^{-1}\end{array}$ & $\begin{array}{c}\text { ESP } \\
\%\end{array}$ & SAR & $\begin{array}{c}\text { Lime } \\
\%\end{array}$ & $\begin{array}{c}B D \\
\mathrm{~g} \mathrm{~cm}\end{array}$ \\
\hline $0-20$ & 8.0 & 92.2 & 16.12 & 20.10 & 14.3 & 73.4 & 77 & 35.3 & 1.26 \\
$20-40$ & 8.3 & 87.0 & 5.45 & 14.10 & 6.4 & 45.6 & 30 & 35.3 & 1.39 \\
$40-60$ & 8.3 & 79.2 & 2.98 & 11.45 & 3.8 & 33.5 & 17 & 37.0 & 1.40 \\
$60-80$ & 8.4 & 71.8 & 1.88 & 8.63 & 1.9 & 22.5 & 14 & 41.6 & 1.56 \\
$80-100$ & 8.3 & 69.0 & 1.33 & 10.28 & 1.6 & 15.3 & 7 & 41.1 & 1.58 \\
\hline
\end{tabular}

$E C_{e}:$ electrical conductivity of the saturation extract; CEC: Exchangeable Sodium Percentage; SAR: Sodium Adsorption Ratio; Exc. Na: Exchangeable Sodium; BD: Bulk Density

\subsection{Leaching water}

The electrical conductivity of the leaching water used in this experiment is $0.520 \mathrm{dS} \mathrm{m}^{-1}$ and the SAR value is approximately 0.45 . The groundwater salinity is $1.72 \mathrm{dS} \mathrm{m}^{-1}$ and the SAR value is 8.2. (Table 2).

Table 2- Chemical properties of the leaching water and groundwater

\begin{tabular}{|c|c|c|c|c|c|c|c|c|c|c|c|}
\hline \multirow{2}{*}{$\begin{array}{l}\text { Water } \\
\text { resource }\end{array}$} & \multirow{2}{*}{$p H$} & \multirow{2}{*}{$\begin{array}{l}E C \\
d S m^{-1}\end{array}$} & \multicolumn{3}{|c|}{ Cations, meq $L^{-1}$} & \multirow[b]{2}{*}{$M g$} & \multicolumn{2}{|c|}{ Anions, meq $L^{-1}$} & \multirow[b]{2}{*}{$\mathrm{SO}_{4}$} & \multirow{2}{*}{ Total } & \multirow[b]{2}{*}{$S A R$} \\
\hline & & & $\mathrm{Na}$ & $K$ & $\bar{C} a$ & & $\mathrm{HCO}_{3}$ & $\mathrm{Cl}$ & & & \\
\hline Leaching water & 8.2 & 0.52 & 0.83 & 0.1 & 1.52 & 5.30 & 3.80 & 0.30 & 3.60 & 7.74 & 0.45 \\
\hline Groundwater & 8.2 & 1.72 & 11.3 & 0.2 & 2.39 & 11.86 & 8.20 & 1.40 & 16.19 & 25.79 & 8.2 \\
\hline
\end{tabular}


FIWGM is the waste generated during the phosphorus fertilizer production in Mersin fertilizer factory. It is in powder form and its purity level is between $85 \%$ and $90 \%$. FIWGM has been applied by hand spread to the soil surface and mechanically mixed with shovels approximately within the $30-40 \mathrm{~cm}$ of soil depth.

\subsection{Experimental set-up}

The research has been designed for remediation trials; data on infiltration have also been provided for these trials. The research was developed with the design of a randomized block of four FIWGM dosage treatments and three replications. The dimensions of the plot are arranged as $3 \mathrm{~m} \times 5 \mathrm{~m}=15 \mathrm{~m}^{2}$.

The soil has been plowed deep with the plow to increase the water permeability at the research site and to ensure that the breeding agent blends well into the soil. In order to prevent leakage to the sides, the edges of the parcel have been covered by a plastic cover, approximately $40-50 \mathrm{~cm}$ deep.

\subsection{Procedures}

Leaching water has been given in $30 \mathrm{~cm}$ portions. When the water was infiltrated, the plots were expected to dry for about three days. After soil samples have been taken from the middle of the plots, the holes were filled with soil and the sampling points were marked with a wooden stake.

Soil and water samples analyzed using the methods described by Richards (1954) and the hydrometer texture (Bouyoucos 1951). Carbonates analyzed by calcimeter, salinity $\left(\mathrm{EC}_{\mathrm{e}}\right)$ analyzed by conductivity meter, CEC and exchangeable sodium $(\mathrm{NaX})$ were determined using a flame photometer (Tüzüner 1990).

\subsection{Assessment of data}

The time of application of water and infiltration has been recorded for each $30 \mathrm{~cm}$ of water depth and for each plot. The infiltration capacity of each treatment has been determined separately. Consequently, the average of these values for each FIWGM treatment has been calculated. Cumulative infiltrated $(Z)$ has been determined using the mean values and infiltration equation (Kostiakov 1932) as follows:

\section{$\mathrm{Z}=\mathrm{KT}^{\mathrm{n}}$}

Where: K, constant; T; time (h) and n, exponent.

\subsection{Exchangeable Na removal}

The theoretical gypsum requirement for each soil depth was calculated using the following equations, taking into account the ESP value below 10:

$\mathrm{GR}=\mathrm{EW} \times 10^{-5} \times \mathrm{A} \times \mathrm{BD} \times \mathrm{D}_{\mathrm{S}} \times\left(\left(\mathrm{ESP}_{\mathrm{i}}-\mathrm{ESP}_{\mathrm{f}}\right) / 100\right) \times \mathrm{CEC}$

$\mathrm{ESP}=(\mathrm{NaX} / \mathrm{CEC}) \times 100$

The following abbreviations have been used in equation; GR; gypsum requirement $\left(\mathrm{cmol}^{+} \mathrm{kg}^{-1} \mathrm{dry}\right.$ weight), EW, the equivalent weight of gypsum ( $\mathrm{cmol}^{+} \mathrm{kg}^{-1}$ dry weight), ESP; exchangeable sodium percentage (\%), ESP $\mathrm{i}_{\mathrm{i}}$ and $\mathrm{ESP}_{\mathrm{f}}$; initial and final ESP value (\%), CEC; cation exchange capacity $\left(\mathrm{cmol}^{+} \mathrm{kg}^{-1}\right), \mathrm{BD}$; bulk density of the soil $\left(\mathrm{g} \mathrm{cm}^{-3}\right), \mathrm{A}$; area $\mathrm{m}^{2}$ and $\mathrm{D}_{\mathrm{s}}$; soil depth $\mathrm{m}, \mathrm{NaX}$; exchangeable sodium, $\mathrm{cmol}^{+} \mathrm{kg}^{-1}$ dry weight.

First, a certain amount of leaching water for each FIWGM, and for each soil layer using the GR equation, and how much gypsum equivalent of the exchangeable sodium removed from the soil profile has been calculated.

\subsection{Boron leaching}

The arithmetic average of three plots was used in all assessments. The remaining boron (B) after leaching was divided by the initial boron value $\left(\mathrm{B}_{0}\right)$ and therefore the values of $\mathrm{B} / \mathrm{B}_{0}$ were obtained by each leaching water depth. For each FIWGM dose, the ratio of leaching water $\left(\mathrm{D}_{\mathrm{lw}}\right)$ to soil depth $\left(\mathrm{D}_{\mathrm{s}}\right)$ has been calculated. Thus, the depth of the leaching water and the boron has been removed independently of the soil depth, and the boron leaching curve and function were obtained as reported by Boumans et al. (1963). 


\section{Results and Discussion}

\subsection{Change of hydraulic properties of soil}

The infiltration rate is a rather sensitive indicator of soil physical conditions. Sodium disrupts the soil structure, disperses soil particles, blocks pores, and slows down the flow of water. When a calcium source is used for soil rehabilitation, the process is reversed and the soil coagulation is regenerated, leading to a noticeable increase in soil porosity.

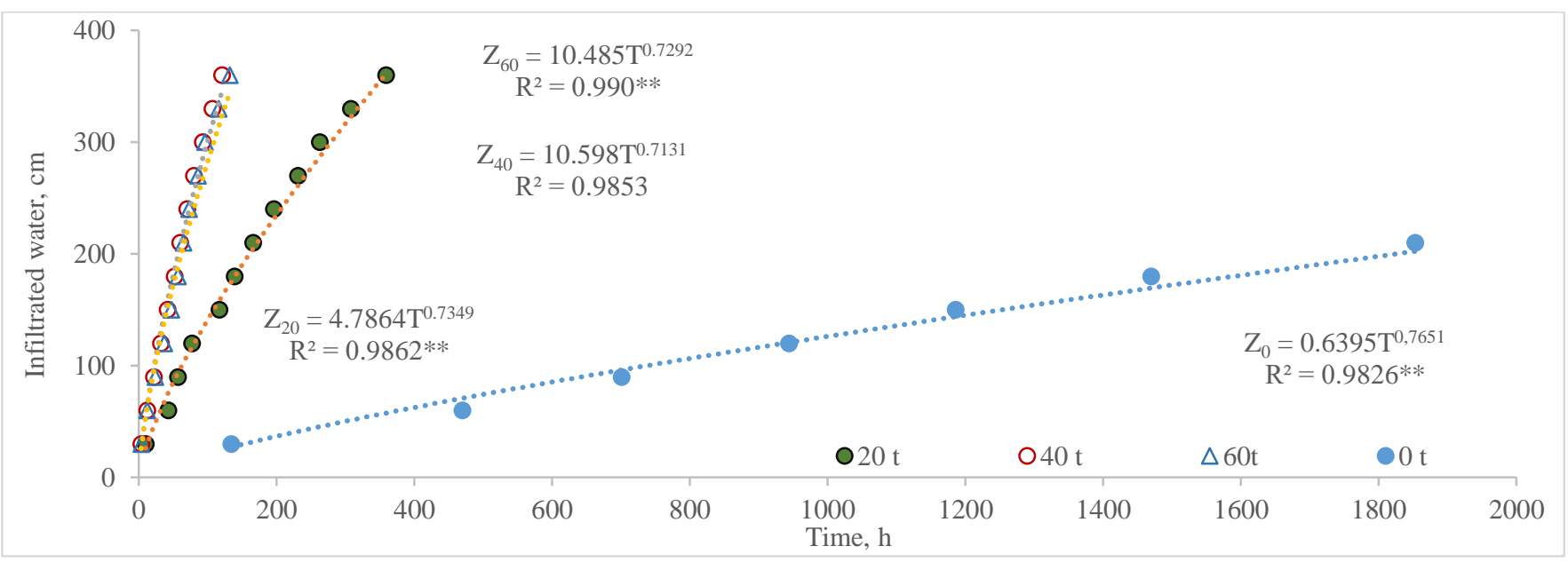

Figure 2- Effect of different doses of FIWGM on infiltration capacity of soil

The passage of water through the soil profile is, therefore, easier and the hydraulic conductivity increases significantly (Qadir \& Scuhbert 2002). These research findings are consistent with the above-mentioned hypothesis. The soil infiltration rate increased as the dose of FIWGM applied increased (Figure 2).

Initially, while the infiltration rate (I) in the plot without FIGWM has been $0.22 \mathrm{~cm} \mathrm{~h}^{-1}$, when 20, 40 and 60 tons of FIWGM have been applied per hectare, the infiltration rates increased to 3.0,8.57, and $8.57 \mathrm{~cm} \mathrm{~h}^{-1}$, respectively (Table 3, Figure 2).

Table 3- Effect of different doses of industrial gypsum on infiltration capacity

\begin{tabular}{|c|c|c|c|c|c|c|c|c|c|c|c|c|}
\hline \multirow{3}{*}{$\begin{array}{c}\text { Applied water } \\
\text { depth, } \mathrm{cm}\end{array}$} & \multicolumn{12}{|c|}{ FIWMG, $t h a^{-1}$} \\
\hline & 0 & 20 & 40 & 60 & 0 & 20 & 40 & 60 & 0 & 20 & 40 & 60 \\
\hline & \multicolumn{4}{|c|}{ Time, $h$} & \multicolumn{4}{|c|}{$I, \mathrm{~cm} \mathrm{~h}^{-1}$} & \multicolumn{4}{|c|}{ Average $\mathrm{I}, \mathrm{cm} \mathrm{h} h^{-1}$} \\
\hline 0 & 134 & 10 & 3.5 & 3.5 & 0.22 & 3.00 & 8.57 & 8.57 & 0.22 & 3.00 & 8.57 & 8.57 \\
\hline 210 & 1853 & 166 & 65 & 60 & 0.08 & 1.11 & 3.75 & 3.75 & 0.11 & 0.18 & 3.23 & 3.50 \\
\hline 330 & - & 308 & 116 & 107 & & 0.67 & 1.50 & 2.14 & & 0.10 & 2.84 & 3.08 \\
\hline 360 & - & 359 & 132 & 121 & & 0.59 & 1.88 & 2.14 & & 0.08 & 2.73 & 2.98 \\
\hline
\end{tabular}

As can be seen, the FIWGM application has enabled significant increases in infiltration rates. In plots where FIWGM was applied, $360 \mathrm{~cm}$ of leaching water has been infiltrated, while in plots without FIWGM, only $210 \mathrm{~cm}$ of leaching water could be infiltrated. In plots where 20, 40 and 60 tons of treatment material have been used, the infiltration rates at the end of the test have been $1.11,3.75$ and $3.75 \mathrm{~cm} \mathrm{~h}^{-1}$, respectively. Exponential relationships with high correlation coefficients have been identified between cumulative infiltration and time for different FIWGM doses (Figure 2).

The use of gypsum on the soil surface has been commonly used for a long time in California to reclamation sodic soils and improve infiltration rates (Oster et al. 1996). The application of gypsum spread to soil has increased the rate of infiltration by $152 \%$ (Raza et al. 2001). The use of gypsum in sodium-affected soils is commonly used to increase aggregate stability and infiltration rates (Agassi et al. 1981; Keren \& Shainberg 1981). Soluble salts promote flocculation in the soil (Keren \& Shainberg 1984) as well as a decrease in the relative sodium content and an increase in the salt content of the water influence the rate of infiltration (Ayers \& Westcott 1985). In this trial, the applying FIWGM developed the physical properties of the soil and provided a significant level of an increase in the rate of infiltration. It was understood that test area soils could not be recovered without the use of any reclamation material due to very low infiltration capacity. Considering the gypsum content of FIWGM, it has been concluded that the expected results of this study had been achieved.

\subsection{Leaching of exchangeable sodium}

In this research, the fertilizer industry waste gypsum material (FIWGM) containing approximately 85-90\% gypsum has been used as a reclamation material. 
While $360 \mathrm{~cm}$ of water has been infiltrated which passes through the profile in the plots where FIWGM is applied, in the plots without FIWGM application, only $210 \mathrm{~cm}$ of water could be infiltrated during the whole phase. Without FIWGM, NaX decreased significantly only in the upper soil. Infiltration capacity was very low in these plots, and the amount of NaX removed was very small and, finally, the soil could not be rehabilitated.

In the FIWGM applied plots, the soil analysis revealed that the exchangeable sodium was removed from the topsoil layers and accumulated in the lower soil layers following the completion of the leaching (Table 4, Figure 3a).

At the end of 20 tons per hectare, FIWGM and 240, 300 and $360 \mathrm{~cm}$ of leaching water applications, the ESP values in the upper layer $(20 \mathrm{~cm}$ ) decreased to 6,8 and 2, respectively (Figure $3 \mathrm{~b}$ ). No more NaX has been leached from the lower layers after 240 and $300 \mathrm{~cm}$ of leaching water. Whereas, at the end of $360 \mathrm{~cm}$ of leaching water, the ESP values decreased below 15 in $100 \mathrm{~cm}$ of the soil profile and ranged between $2-12 \%$ across the entire profile (Table 4).

Table 4 - Average exchangeable sodium $(\mathrm{NaX})$ and exchangeable sodium percentage (ESP) of soils prior to and after leaching with 240,300 and $360 \mathrm{~cm}$ water

\begin{tabular}{|c|c|c|c|c|c|c|c|c|c|c|c|}
\hline \multirow{2}{*}{$\begin{array}{r}\text { FIWGM } \\
\text { applied } \\
t h a^{-1} \\
\end{array}$} & \multirow{2}{*}{$\begin{array}{l}\text { Soil depth } \\
\mathrm{cm}\end{array}$} & \multirow{2}{*}{$\begin{array}{l}\text { Bulk density } \\
\quad \mathrm{g} \mathrm{cm}^{-3}\end{array}$} & \multicolumn{3}{|c|}{ Leaching water, } & & \multirow{2}{*}{$\begin{array}{l}C E C \\
\mathrm{cmol}^{+} \mathrm{kg}^{-1}\end{array}$} & \multicolumn{4}{|c|}{ Leaching water } \\
\hline & & & \multicolumn{4}{|c|}{$\begin{array}{cccc}0 & 240 & 300 & 360 \\
& \mathrm{NaX}_{\mathrm{cmol}} \mathrm{cmol}^{+} \mathrm{kg}^{-1},\end{array}$} & & \multicolumn{4}{|c|}{$E S P$} \\
\hline \multirow{3}{*}{0} & $0-20$ & 1.26 & 11.51 & 9.47 & - & - & 18.41 & 62 & 51 & - & - \\
\hline & $20-40$ & 1.39 & 5.57 & 9.56 & - & - & 12.65 & 44 & 52 & - & - \\
\hline & $40-60$ & 1.40 & 2.20 & 4.50 & - & - & 10.00 & 22 & 45 & - & - \\
\hline \multirow{3}{*}{20} & $0-20$ & 1.26 & 11.07 & 1.04 & 1.35 & 0.36 & 17.37 & 64 & 6 & 8 & 2 \\
\hline & $20-40$ & 1.39 & 3.69 & 2.59 & 4.55 & 1.2 & 12.72 & 29 & 21 & 38 & 9 \\
\hline & $40-60$ & 1.40 & 2.01 & 2.60 & 3.6 & 0.67 & 10.48 & 19 & 25 & 34 & 12 \\
\hline \multirow{3}{*}{40} & $0-20$ & 1.26 & 11.79 & 1.45 & 1.13 & 0.67 & 17.96 & 65 & 8 & 6 & 4 \\
\hline & $20-40$ & 1.39 & 5.36 & 1.63 & 1.5 & 1.61 & 12.94 & 41 & 13 & 12 & 12 \\
\hline & $40-60$ & 1.40 & 3.37 & 2.65 & 1.62 & 1.55 & 10.56 & 32 & 25 & 15 & 15 \\
\hline \multirow{3}{*}{60} & $0-20$ & 1.26 & 10.23 & 1.17 & 0.98 & 0.68 & 17.51 & 58 & 7 & 6 & 4 \\
\hline & $20-40$ & 1.39 & 5.19 & 1.43 & 1.99 & 2.24 & 12.18 & 43 & 12 & 16 & 18 \\
\hline & $40-60$ & 1.40 & 2.34 & 2.06 & 1.86 & 2.67 & 10.73 & 22 & 19 & 17 & 25 \\
\hline
\end{tabular}

However, even when 40 tons per hectare of industrial gypsum and $240 \mathrm{~cm}$ of leaching water have been used, the ESP values in the $40 \mathrm{~cm}$ soil profile dropped to safe values. When the water depth of the leaching is $300 \mathrm{~cm}$, the ESP values in the $100 \mathrm{~cm}$ profile have dropped below $15 \%$, except for the soil depth of $60-80 \mathrm{~cm}$. When $360 \mathrm{~cm}$ of leaching water has been applied, the ESP values have been lower than $15 \%$ in the entire profile (Figure $3 \mathrm{c}$ ).

However, the application of $60 \mathrm{t} \mathrm{ha}^{-1}$ of FIWGM could not provide for further sodium removal in all leaching waters (Figure 3d). From this point on, it has been concluded that the applied irrigation water was not sufficient to dissolve more FIWGM.

(a)

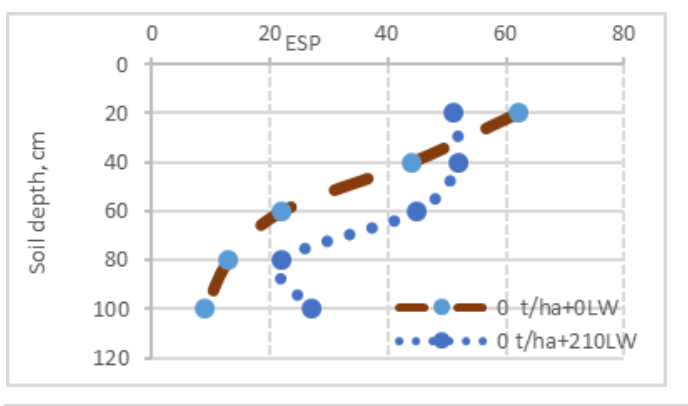

(c)

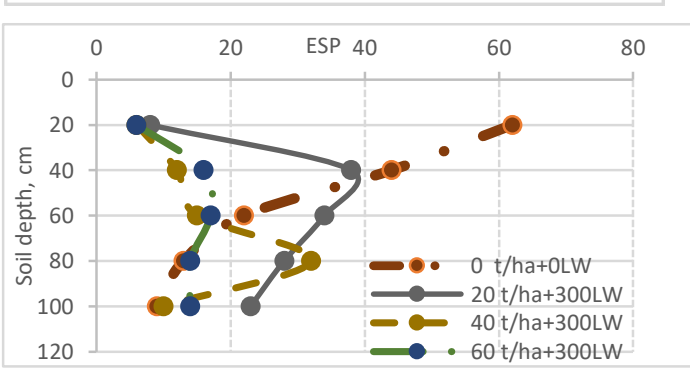

(b)

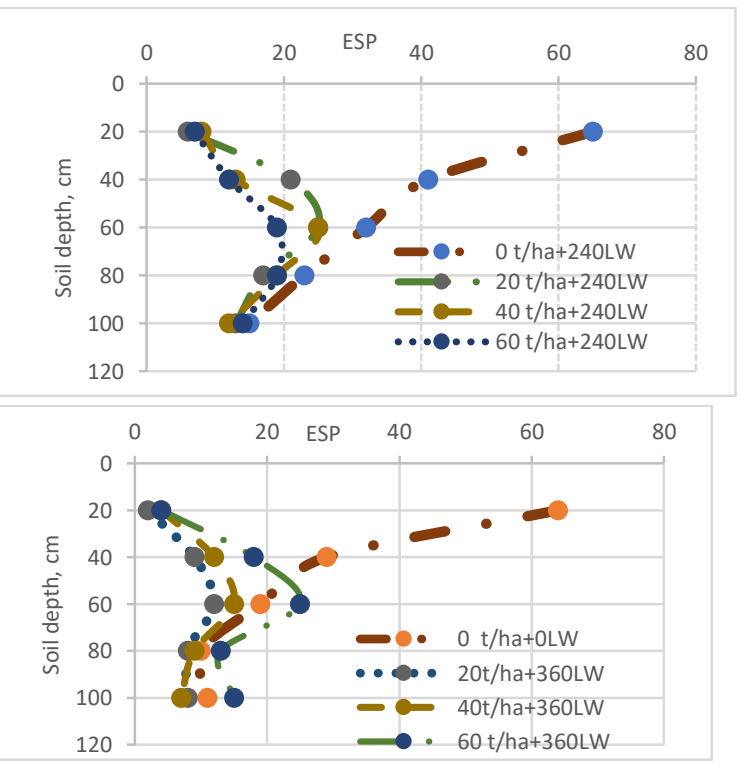

Figure 3- Effect of different leaching water (LW) at different FIWGM dosages on change ESP at the soil profile 
A similar situation has also been observed in some studies, and it has been observed that the administered FIWGM dose increases and the sodium removed for each mined gypsum unit decreases (Beyce 1977, Bahçeci 2008).

Overall, the results have shown that favorable leaching of interchangeable sodium at the site of the test site is not possible without some kind of reclaimed chemical material. Therefore, in recent years, lower doses have been recommended instead of the theoretically calculated amount of gypsum.

\subsection{Gypsum calibration curves for sodic soils reclamation}

Table 5 shows the quantities of theoretical gypsum calculated for the removal of the exchangeable Na at different soil depths and at two leaching water levels. As can be seen, in plots where FIWGM has not been applied, sodium leached is approximately 4.420 tons per hectare equivalent to gypsum.

Table 5- Theoretical amounts of gypsum calculated for the replaced exchangeable Na with amendments in different doses on the sodic soils

\begin{tabular}{|c|c|c|c|c|c|c|}
\hline \multirow{3}{*}{$\begin{array}{c}\text { FIWGM } \\
\text { applied } \\
t h a^{-1}\end{array}$} & \multirow{3}{*}{$\begin{array}{c}\text { Soil } \\
\text { Depth, } \\
(\mathrm{cm})\end{array}$} & \multicolumn{2}{|c|}{ Leaching water, $(\mathrm{cm})$} & \multirow{3}{*}{$\begin{array}{c}\text { Soil } \\
\text { Depth, } \\
(\mathrm{cm})\end{array}$} & \multicolumn{2}{|c|}{ Leaching water, $(\mathrm{cm})$} \\
\hline & & & 360 & & 300 & 360 \\
\hline & & $\begin{array}{r}\text { The } \\
\text { calculated } f\end{array}$ & $a X,\left(t h a^{-1}\right)$ & & \multicolumn{2}{|c|}{$\begin{array}{l}\text { Cumulative removed, } \\
\operatorname{NaX}\left(t h a^{-1}\right)\end{array}$} \\
\hline \multirow[t]{2}{*}{0} & $0-20$ & 4.420 & 4.420 & 20 & 4.420 & 4.420 \\
\hline & $0-20$ & 21.07 & 23.21 & 20 & 21.07 & 23.21 \\
\hline 20 & $20-40$ & & 5.95 & 40 & 21.06 & 29.16 \\
\hline \multirow{5}{*}{40} & $0-20$ & 23.10 & 24.10 & 20 & 23.10 & 24.10 \\
\hline & $20-40$ & 9.23 & 8.97 & 40 & 32.33 & 33.06 \\
\hline & $40-60$ & 4.21 & 4.38 & 60 & 36.54 & 37.45 \\
\hline & $60-80$ & & 3.43 & 80 & 36.54 & 40.88 \\
\hline & $80-100$ & 1.30 & 1.96 & 100 & 37.85 & 42.84 \\
\hline \multirow{3}{*}{60} & $0-20$ & 20.05 & 20.70 & 20 & 20.05 & 20.70 \\
\hline & $20-40$ & 7.65 & 7.05 & 40 & 27.70 & 27.75 \\
\hline & $40-60$ & 1.16 & . & 60 & 28.85 & 27.75 \\
\hline
\end{tabular}

Whereas 20 tons per hectare of FIWGM and 300 and $360 \mathrm{~cm}$ of leaching water have been used, 24 and 29 tons of gypsum sodium equivalent have been removed, respectively. In a previous study conducted at this research site, the application of 20 and 40 tons per hectare of mined gypsum, along with $360 \mathrm{~cm}$ of gypsum leaching water, removed an exchangeable sodium equivalent of 38 and 56 tons of gypsum per hectare (Bahçeci 2008).

As can be seen in Figure 4, when 40 tons of FIWGM were applied per hectare, the quantity of sodium leachable removed from the soil profile is approximately 43 tons per hectare. However, as the doses of FIWGM increase, the amount of exchangeable sodium leached did not increase at the same rate. The effect of the treatment material at lower doses was higher and the effect of the treatment agent at high doses applied to the removal of interchangeable sodium was found to be lower.

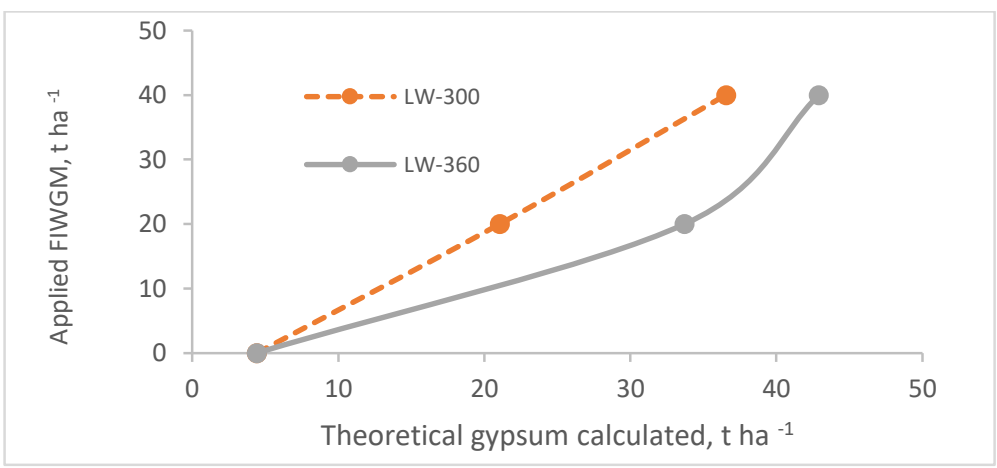

Figure 4- Gypsum calibration curves at two leaching waters levels for $100 \mathrm{~cm}$ soil profile

The amount of FIWGM required can be estimated to reclaim sodic-soil using these calibration curves in Figure 4 . For example, if the required FIWGM was theoretically calculated at 20 tons per hectare, in this case 10 tons per hectare of FIWGM and $360 \mathrm{~cm}$ of leaching water used, the quantity of exchangeable sodium removed would be 20 tons per hectare of gypsum equivalent for $100 \mathrm{~cm}$ of soil depth.

The time required to infiltrate the applied water is estimated to be approximately 380 hours or 16 days using the cumulative infiltration curve in Figure 2. The time required for improvement is calculated by adding weighting intervals to the infiltration time. 


\subsection{Boron leaching}

High boron concentrations were formed in the experimental area by the evaporation of shallow groundwater. Consequently, while the upper layer of the soil has a high boron excess in the research area, the boron concentration in the lower layers has been low.

To improve is very difficult boron soils. The amount of water required for boron leaching in soils with a high boron content by nature is approximately twice the amount required for salt leaching (USSL 1981; Hoffman 1986). Rehabilitation of boron soils is costly and time-consuming and labour-intensive. However, it is still a common view that more accurate and consistent results are obtained with on-site field trials.

In this research, along with leaching water applications, the boron content also decreased and, at the end of $360 \mathrm{~cm}$ of leaching water, the boron concentration decreased to $2 \mathrm{ppm}$ in the upper soil and lower levels in the lower layers (Table 6, Figure 5).

As explained in the method, using the average data obtained, a regression analysis has been conducted to determine the relationship between the boron left after leaching and the ratio of the water depth applied to the soil depth based on the initial boron concentration in the soil.

Table 6- Average boron status (ppm) in test plots before and after leaching

\begin{tabular}{lcccccccc}
\hline \multirow{2}{*}{ Soil depth, cm } & \multicolumn{7}{c}{ Leaching water, cm } \\
\cline { 2 - 9 } & 0 & 30 & 60 & 120 & 180 & 240 & 300 & 360 \\
\hline $0-20$ & 13.30 & 9.17 & 10.23 & 5.72 & 3.87 & 2.27 & 3.03 & 2.08 \\
$20-40$ & 3.74 & 3.45 & 5.90 & 4.82 & 3.62 & 1.32 & 1.41 & 1.88 \\
$40-60$ & 2.73 & 0.97 & 2.78 & 2.04 & 1.83 & 1.52 & 1.80 & 0.50 \\
$60-80$ & 1.19 & 0.18 & 2.30 & 1.04 & 1.38 & 0.10 & 1.61 & 0.15 \\
$80-100$ & 1.89 & 0.56 & 0.90 & 0.81 & 1.26 & 0.20 & 1.15 & 0.10 \\
\hline
\end{tabular}

A statistically significant logarithmic relationship between leaching water depth $\left(D_{\text {lw }}\right) /$ soil depth $\left(D_{s}\right)$ and remaining boron/initial boron values $\left(\mathrm{B} / \mathrm{B}_{\mathrm{o}}\right)$ has been identified. As a result of the regression analysis, the equation obtained is as follows: $\mathrm{B} / \mathrm{B}_{\mathrm{o}}=0.622-0.168 \mathrm{Ln} \mathrm{D}_{\mathrm{lw}} / \mathrm{D}_{\mathrm{s}},\left(\mathrm{R}^{2}=0.921^{* *}\right)$.

As can be seen, the resulting equation has a high correlation coefficient, which is statistically significant at $\mathrm{p}=0.01$.

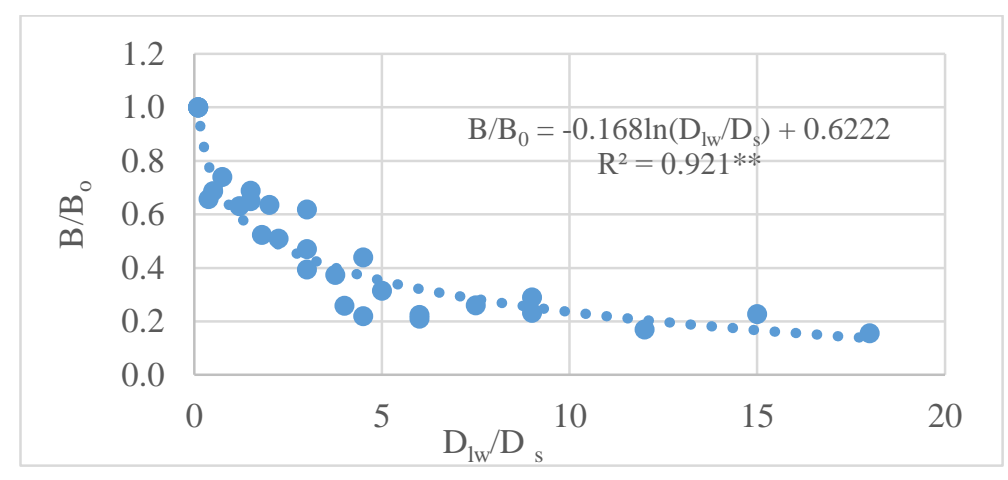

Figure 5- Boron leaching curve

\section{Conclusions}

The field experiments have demonstrated that an increase in FIWGM application rate up to 40 tons per hectare has resulted in significant increase in the removal of exchangeable sodium. Results also indicated that the application of 20 tons FIWGM per hectare, along with 300 and $360 \mathrm{~cm}$ water could remove the exchangeable sodium equivalent to 23.21 and 29.16 tons per hectare gypsum, respectively.

When 40 tons of FIWGM have been used per hectare, sodium equivalent to 42.89 tons of gypsum has been removed from the soil profile. Whereas, if 60 tons of FIWGM was applied to a hectare with 300 and $360 \mathrm{~mm}$ of leaching water, the amount of sodium leached has been only 28.85 and 27.75 tons of equivalent gypsum, respectively. This suggests that the quantity of water applied has not been sufficient to dissolve the FIWGM applied at high doses.

Since soil infiltration capacity has been very low, it is highly recommended to start with the application of 10 tons per hectare of FIWGM and to increase the amount of application needed to gradually remove salts and sodium exchangeable from the soil profile. 


\section{References}

Agassi M, Shainberg I \& Morin I (1981). Effect of electrolyte concentration and soil sodicity on the infiltration rate and crust formation. Soil Sci.Soc. A. J. 45: 848-851

Ayers R S \& Westcott D W (1985). Water Quality for Irrigation. FAO Irrigation and Drainage Paper 29. FAO: Rome.

Bahçeci İ (2008). Determination of salt leaching and gypsum requirements with field tests of saline-sodic soils in Central Turkey, Irr. and Drainage 58(3):332-345. https://doi.org/10.1002/ird.406

Beyce Ö (1977). A Study on the Determination of the Amount of Leaching Water and Improvement Agents in Salty and Sodium Soils in Some Irrigation Development Areas of Turkey, Merkez TOPRAKSU Research Institute. Gn.Spring. no. 44, Serial No: T-25. 143 s. (in Turkish with an abstract in English)

Boumans J H, Hulsbes W C, Lindenbergh H L J \& Sluis, P M van der (1963). Reclamation of salt affected soil in Iraq. Int. Inst. Ld Reclam. Improv. Pub. no. 11.

Bouyoucos G S (1951). A recalibration of the hydrometer method for making mechanical analysis of soils. Agronomy Journal 43: 434-448

Diacono M \& Montemurro F (2015). Effectiveness of Organic Wastes as Fertilizers and Amendments in Salt-Affected Soils Agric. 2015, 5, 221-230. doi:10.3390/agriculture 5020221

FAO (2019). FAO Soil Portal, Food and Agricultural Organization of the United Nation http://www.fao.org/home/en/

Gharaibeh M A, Eltaif N I \& Shra'ah S H (2010). Reclamation of a calcareous saline-sodic soil using phosphoric acid and by-product gypsum. Soil Use Management 26(2):141-148. https://doi.org/10.1111/j.1475-2743.2010.00260.x

Gill J S, Sale P W G, Peries R R \& Tang C (2009). Changes in physical properties and crop root growth in dense sodic subsoil following incorporation of organic amendments, Field Crops Res. 114:137-146. https://doi.org/10.1016/j.fcr.2009.07.018

Gupta R K \& Abrol I P (1990). Salt-affected soils: their reclamation and management for crop production. Adv Soil Sci 11:223-288

Haque N A, Haque M E, Hossain M E, Khan M K \& Razzaque A H M (2015). Effect of Farm Yard Manure, Gypsum and Nitrogen on Growth and Yield of Rice in Saline Soil of Satkhira District, Banglades, Journal of Bioscience and Agric. Research, vol. 3(2), 2015, p. 65-72. https://doi.org/10.18801/jbar.030215.32

Hanay A, Büyüksönmez F, Kızıloğlu F M \& Canbolat M Y (2013). Reclamation of Saline-Sodic Soils with Gypsum and MSW Compost, Compost Science \& Utilization. https://doi.org/10.1080/1065657x.2004.10702177

Hoffman G J (1986). Guidelines for reclamation of salt-affected soils. Applied Agricultural Research 1(2):65-72

Hussain N S, Mehdi M, Khan G D \& Iqbal Z (2001). Industrial wastes as reclaimant for sodic soils. Pakistan J. Bio. Sci. 4(3): 193-195

Keren R \& Shainberg I (1981). Effect of dissolution rate on the efficiency of industrial and mined gypsum in improving infiltration ofa sodic soil. Soil Sci. Soc.Am.J. 45: 103-107

Keren R \& Shainberg I (1984). Colloid properties of clay minerals in saline and sodic solutions. In Soil Salinity under Irrigation, Shainberg I, Shalhevet J, (eds). Springer-Verlag: Berlin.

Kostiakov A N (1932). On the dynamics of the coefficient of water percolation in soils and on the necessity for studying it from a dynamic point of view for purposes of amelioration. In: Trans. 6th Comm. Int. Sot. Soil Sci. Russian Part A: 17-21

Mace J E, Amrhein C \& Oster J D (1999). Comparison of gypsum and sulfuric acid for sodic soil reclamation. Arid Soil Res Rehabilitation 13: $171-188$

Martinez-Beltran J \& Manzur C L (2005). Overview of salinity problems in the world and FAO strategies to address the problem. Proc. Int. Salinity Forum. Riverside, California, April 2005, pp. 311-313

Oster J D, Shainberg I \& Abrol J P (1996). Reclamation of salt-affected soil. In Soil Erosion, Conservation and Rehabilitation, Agassi M (ed.). Marcel Dekker: New York; 315-351

Örs S, Sahin Ü \& Khadra R (2014). Reclamation of Saline Sodic Soils with the Use of Mixed Fly Ash and Sewage Sludge, Arid Land Res. and Management Vol. 29, 2014-Issue 1

Qadir M, Schubert S, Ghafoor A \& Murtaza G (2001). Amelioration strategies for sodic soils: a review. Land Degradation Development Vol.12: 357-386

Qadir M \& Schubert S (2002). Degradation process and nutrient constraints in sodic soils. Land Degradation Development Vol. 13:275-294

Raza Z I, Rafiq M S \& Abdur R (2001). Gypsum application in slots for reclamation of saline sodic soils. Int. J. of Agric. and Biology 3(3): 281-285

Richards L A (1954). Diagnosis and Improvement of Saline and Alkaline Soils, United States Salinity Staff, Agricultural Handbook 60, US Department of Agriculture, Washington DC.

Singh Y P, Dubey U C, Singh S \& Dubey S K (2013) Interventions of Sodic Soil Reclamation Technologies and Constraints in their Adoption", Indian Research Journal of Extent and Education, vol. 13(2), 2013, p. 36-40

Singh Y P, Arora S, Mishra V K, Dixit H \& Gupta R K (2017). Composting of municipal solid waste and farm wastes for its use as amendment in sodic soil. Journal of Soil and Water Conservation 16(2): 172-177. https://doi.org/10.5958/2455-7145.2017.00025.x

Sisoday V \& Vaghani M (2016). Reclamation of Saline and Sodic Soil: The State of GRD Journals Global Research and Development Journal for Engineering | Recent Advances in Civil Engineering for Global Sustainability | March 2016

Tüzüner A (1990). Handbook of Soil and Water Analysis Laboratories. General Directorate of Rural Services. (in Turkish)

USSL (1981). Salinity management in agriculture. (US Salinity Laboratory Staff) Given in Irrigation Challenges of the 80s as in preparation in 1981

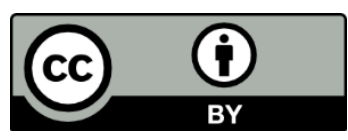

(C) 2022 by the author(s). Published by Ankara University, Faculty of Agriculture, Ankara, Turkey. This is an Open Access article distributed under the terms and conditions of the Creative Commons Attribution (CC BY) license (http://creativecommons.org/licenses/by/4.0/), which permits unrestricted use, distribution, and reproduction in any medium, provided the original work is properly cited. 